The Chairman thanked Professor Wild for his words and called upon Professor B. Strömgren, President of the International Astronomical Union, to speak.

\title{
ADDRESS BY THE PRESIDENT OF THE INTERNATIONAL ASTRONOMICAL UNION,
} PROFESSOR B. STRÖMGREN

'Mr Lord Mayor, Dr Paul Wild, Mr Vice-Chancellor O'Neil, Dr Harley Wood, Ladies and Gentlemen,

The warm words of welcome to which we have just listened, spoken in the beautiful Sydney Town Hall, have been deeply appreciated, and on behalf of the International Astronomical Union I wish to express our sincere gratitude.

To you, Mr Lord Mayor, I wish to say that we are most happy that the Fifteenth General Assembly is taking place in your city. Already so much has been done for us to make our meeting a success, and we have been met with so much kindness and friendliness on the part of our hosts in Sydney that we feel very much at home. Most of us have come a long way to this General Assembly, and it has been a thrilling experience to get to know this fine city, with its many interesting landmarks and beautiful sights, with its magnificent harbour.

We are particularly grateful to you, Mr Lord Mayor Griffin, for the opportunity to hold the Inaugural Ceremony in the Sydney Town Hall and for the invitation to the beautiful reception that preceded it. I wish to thank you very much indeed.

Dr Paul Wild, I beg you to receive, as representative of the Australian Academy of Science, the sincere thanks of the International Astronomical Union. As one of the Host Organizations the Academy has played a highly appreciated active rôle in the preparations of the Fifteenth General Assembly. The great importance of your Academy in the scientific life of Australia is well known to us, and we are honoured and happy to hold our meeting under the auspices of the Australian Academy of Science. I wish to express warm thanks for your words of welcome, and I ask you to convey our gratitude to the Australian Academy of Science.

Dr O'Neil, I thank you most sincerely for your very kind words, and on behalf of the International Astronomical Union I wish to tell you how grateful we are to the University of Sydney for its most important contribution in support of the Fifteenth General Assembly of the IAU. We are all aware of the great burden put on a University that is a host to our General Assembly, and we wish to thank you for inviting us here and for providing such very excellent facilities for our meeting. It is a source of satisfaction to hold our General Assembly at a great University where Astronomy is so strongly represented and supported.

Dr Harley Wood, as Chairman of the Local Organizing Committee you have worked tirelessly and hard during the three years since our last General Assembly. We of the IAU owe you very much indeed, and I wish to tell you here how very grateful we are for all you have done for us. I should like to express to you and the members of the Local Organizing Committee special thanks from the Officers of the IAU. Through the whole period of preparation your most efficient help and fine cooperation have been invaluable and greatly appreciated.

In the life of the International Astronomical Union our Australian colleagues have played, and play a great rôle. Through many decades they have come regularly to the IAU meetings and contributed a most valuable scientific input. For astronomers in other parts of the world the opportunities to meet and have scientific discussions with colleagues from Australia have been most valuable.

And now a strong representation of the IAU community of astronomers is here for the General Assembly. This General Assembly serves many purposes, but a very important one is certainly to further strengthen the ties with our Australian colleagues.

We knew beforehand of the impressive facilities and the splendid achievements of astronomers in Australia. Yet, now that we are here, we appreciate all this even more.

The range of the astronomical activites in Australia is so striking. Let me mention astrometry 
first. The contributions to the undertaking of the Astrographic Catalogue are very extensive. Important work in this and other fields of Astrometry continues, as was quite clear at the recent IAU Symposium in Perth. Solar Astronomy is most strongly represented, and with the great development at Siding Spring contributions in observational optical astronomy will become even more important than has been the case up to now. The intensity interferometer has yielded remarkable results and Australia is making significant contributions in high-energy astrophysics and space astronomy.

And the Australian contributions in the whole range of radio astronomy that started right after World War II have developed into a magnificent and many-faceted effort of the greatest importance in Astronomy.

It is a wonderful chance for the participants in the Fifteenth General Assembly to get even better acquainted with the whole spectrum of these activities and to meet during these weeks for discussions in depth with Australian colleagues and friends.

We are most happy to be here, and on behalf of the International Astronomical Union I wish to say: Thank you so much for asking us to come.'

After Professor Strömgren's words of thanks, the Chairman formally declared the Welcoming Ceremony closed. 